The Sri Lanka Journal of the Humanities (2018) 42: 1-2, 29-53

DOI: http://doi.org/10.4038/sljh.v42i1-2.7254

Published online: 28 November 2019

(C) University of Peradeniya

\title{
Placing Ethnicity: The Sri Lankan English Writer and the Politics of Identity ${ }^{1}$
}

\author{
SIVAMOHAN SUMATHY ${ }^{1}$ \\ ${ }^{1}$ Department of English, University of Peradeniya \\ ${ }^{1}$ sivamohan.sumathy@gmail.com \\ 1 (iD) https://orcid.org/0000-0002-3462-7384
}

The topic I have chosen to write on poses a difficult theoretical question to me, one that I am compelled to answer in the course of this article. Who is the English writer? The title assumes and takes for granted a category of writers in Sri Lanka as English writers, as special and different from other writers in the country. How does one become a writer in English? What constitutes the writer in English? Who is the Sri Lankan English writer? Where ethnicity is concerned, Sri Lanka itself becomes a very fraught category fought over with sweat and blood, toward nobody's gain in the final analysis. When one talks of the ethnic conflict and the English writer one is also forced to examine the idea of Sri Lanka and its own emergences as much as those of the English writer. As I am unable to engage in a full-length examination of all of

\footnotetext{
${ }^{1}$ I wish to express my indebtedness to my colleague Nihal Fernando for all the assistance he rendered me in the course of my writing this paper.
} 
these assumptions, I shall ask the reader to go along with my assertion that the English writer enables Sri Lanka as much as Sri Lanka enables the English writer, dynamically forming its centres and margins. I shall then attempt a partial examination of this dynamism, in the course of which one is forced to address the construct of the writer in English as she is and comes to be. I shall approach this autobiographically and as a 'creative' 'academic' writer. This is another divide that I am uncomfortable with, but for the purposes of this paper, decline to explore and problematize further. Taking the creative writer as an unproblematic category, I proceed to launch into my exploration of the creative writer in English and the ethnic conflict ${ }^{2}$.

The ethnic conflict has enabled particular modes of subjectivities for the English writer, who is different from one another and is also differentiated in her/his situatedness within the ideological and sociopolitical make up of Sri Lankan society. One may say that the Sri Lankan state has been an ethnic one from its very inception and that the Sri Lankan English writer is positioned within that form. In the " 40 s and ' 50 s, the early years of the independence and pre-independence period, conflicts and anxieties over the newborn state and nation were not articulated as ethnic. There were anxieties over 'communalism,' communalism being seen as discriminating against and marginalizing the minorities. The postcolonial is important since, through the idea of the postcolonial, we, as readers, critics, writers and the general mass of people, are able to tease out some of the national and global underpinnings of the state, while holding the global the local and the national together to articulate in very specific terms the national and the internal fault lines within the nation. Thus, I try to work through the idea of the postcolonial and the national, in order to locate the English writer in Sri Lanka, plotting the changing vicissitudes of her station through the trajectory of the ethnic conflict.

\footnotetext{
${ }^{2}$ Of course, the creative writer is another of those emergences that interweaves with the others. But its own discursive conjunctures are not dealt with here.
} 


\section{The Rise of the English Writer: The Postcolonial State and the State of the Academy}

The postcolonial state of Sri Lanka came into its own in 1948. This momentous event, hard fought for, at least in some elite circles, and by middleclass activists and workers, also brought into the open other subjectivities and emergences. From colonial times to our postcolonial days today in the $21^{\text {st }}$ century, English has remained the language of dominance and hegemony, now much more than before, at least in some senses of hegemony. In the first flush of independence and the more disquieting times of the ' $50 \mathrm{~s}$, when the independent state was under strain of some kind, there was a clamour from those kept outside the elite circles to be brought into the fold, to belong more fully. Challenging the status quo leading to a broadening of the bourgeois state's parameters also meant challenging the exclusivity of English and the hegemony of the language, at least rhetorically, while reality itself might have been different. Whatever the case might be, the English writer of the '50s, '60s and '70s felt a nagging doubt on her or his side as to where exactly she belonged, about whether she belonged to the postcolonial nation of Sri Lanka, or Ceylon at that time, and if she did, on exactly what terms she actually belonged. The Sinhala Only act of 1956, which made Sinhala the foremost official language of the country, dislodged the English speaker of first language competence from the sense of security she had felt as a privileged being. S/he had to renegotiate her terms of existence viz-a-vis the nation.

From the 50's to the 70's, in the first flush of the birth of the independent state, further mediated by ' 56 , ethnicisation remains dormant and yet rather potent in the writings of the English speaker. The writings of these times, marked the writer, I mean the English writer, as one removed from mainstream Sinhala dominant politics and political emergence. They like others were a special breed of English writers and not just writers and therefore occupied a tangential position viz a vis the emerging state and emerging Sinhala-Only consciousness. The English writer had to mediate her relation to the state via the growing sentiment of nationalism in the politico-cultural sense and find a way of inserting himself/herself into that. 
The English writer writes about Sri Lankans now, the rural people, and when she does, it cannot only be about the victimized and dispossessed but has to be about the emergences of a lower-middleclass non-urban political force. The English writer has to deal with the 'Other' in terms renewed, the Sinhala 'Other', in ways that assimilated her to the nation, not only as a writer, but as a Sri Lankan writer-a Sri Lankan writer in English writing about becoming Sri Lankan. The early works of Puniyakante Wijenaike, Yasmine Gooneratne, Ashley Halpe and Regi Siriwardene testify to this consciousness, of being marginal, yet dominant and of being not too Sinhala, yet Sri Lankan. The writers here contribute to a sense of belonging that is deeply felt by these writers, contributing to a sensibility of being Sri Lankan writers among a mass of other writers, writing in Sinhala mainly, and to a lesser extent, also in Tamil. The English writer carves out a space of operation for English speakers, readers, listeners, critics and followers, a positionality that marks them as exclusively English speaking and exclusively Sri Lankan. Their primary relationship is to the Sri Lankan nation via English. They profess their intimacy with the Sri Lankan nation. Ethnicity is not really a question here.

Despite the riots of ' 58 (or the anti-Muslim riot of 1914) or the Sathyagrahas of the ' $50 \mathrm{~s}$ and ' $60 \mathrm{~s}$ staged by the 'moderate' Tamil Federal Party, the Sri Lankan English writer remains securely placed within the urban enclaves of Colombo and Kandy, exclusive spaces of English speech, music and drama. I, in no way, want to suggest that people in other parts of the country did not participate in creating English speaking communities, either as bilinguals or as exclusively as the urbanites did in Colombo and Kandy. They did so in multiple ways in other places-In Galle, Jaffna, Batticaloa, Nuwaraeliya and in countless other places. But what I want to underline here is that these 'other' urban spaces developed a contract with the centers, the centre of capital and politics, Colombo, and was compelled to play heed to its tunes, rather dutifully much of the time. Also, while Colombo might have dominated, the other urban and semi-urban spaces in which the writer grew and started writing about did not contribute to an exclusive subjectivity for the English writer. 
With the above thoughts in mind, I map certain positions and subjectivities for the English writer in Sri Lanka vis-à-vis the increased ethnicisation of the Sri Lankan polity and within the postcolonial conundrums of identities that emerge through the ongoing ethnic conflict. I am not a disinterested researcher/critic and I place myself somewhere along the nodes of writing on ethnicity, both as researcher and writer, blended into one. I say this not disingenuously. How does the English writer become? Ungrammatical or awkward as my question might be, it has a rhetorical value for me, as I take the journey from Jaffna to Peradeniya, Jaffna to Colombo in the late '70s and early '80s. I came to Peradeniya, or first Dumbara campus in Polgolla, exotic with its rivers, banks, dam and valley, and all as a first year student at the University. English was one of the academic subjects that I opted to study, one that I proceeded to specialize in after the first year. At Peradeniya, me and other students, as a collective body of learners and heralders, were introduced to a definitive idea of the English writer in Sri Lanka. We were introduced to Lakdasa Wickramasinha, Jean Arasanayagam, Yasmine Gooneratne, of course, Puniyakante Wijenaike and a few others as forming the coterie of English writers in Sri Lanka. Sri Lankan (read Sinhala) was a given and the English writer within the confines of Sri Lanka was a non-ethnic (again read Sinhala) Sri Lankan.

I shall continue in the autobiographical vein a little longer, as my own history evokes the history of the ethnic conflict as I/we know it. When our slow train first approached Kadugannawa which I boarded in Polgahawela and experienced the dizzy heights and the dazzle of the sight that I cannot tire of even today, after so many years, I was inside my A/Level history text. I cannot say with what amazement I passed Balana $^{3}$. I had not felt history before, not knowing that Jaffna could contain history. Jaffna was home; it was not in any history book. This

\footnotetext{
${ }^{3}$ It's with another kind of amazement that I came across, at the tail end of writing this paper, an early poem of Kamala Wijeratne called 'From Balana,' (The Smell of Araliya, 1), underscoring the point I was trying to make regarding my sense of alienation from dominant history. In the poem Wijeratne speaks of 'a proud race' that stood up for just one moment to the invaders. The invaders would be the 'Tamils' in another poem in the same volume, 'I will not forget Dutugemunu' 25-26.
} 
has not happened to us in Jaffna ${ }^{4}$. Like Sri Wickramarajasinha and Mayadunne, Gannoruwa and Kotte, the Sri Lankan writer occupied a social and class landscape as distant as Jaffna was distant from the canonical centres of Colombo and Kandy. As a student growing up in Jaffna, beyond some smattering of folk lore about Sangiliyan who had apparently massacred 600 Catholics in Mannar and Arumuga Navalar, Sri Lankan history bore no relation to who I was, except through a negative dialectic. It was no doubt with a sense of exhilaration, but also with a sense of unarticulated, yet uneasiness and trepidation that I began to find ways of integrating with the idea of Sri Lankan English, even as I felt alienated as a young student of English at Peradeniya in the post 1977 period as a Tamil student from Jaffna not knowing a word of Sinhala. Puniyakante Wijenaike's Giraya becomes a Sri Lankan novel, while, Jean Arasanayagam, becomes famous for the "Ruined Gopuram" precisely for the 'exoticisation' of Jaffna, a space that remains exotic not just for the writer but also for the critic: a Sri Lankan writer exoticising Jaffna. Jean Arasanayagam has her birth as a Sri Lankan writer precisely because she writes about another space, the exotic space of Jaffna, which I suddenly realized was my home after all. Yet, Jean Arasanayagam's overture to ethnicity in "Ruined Gopuram" makes an overture to me; it did offer a point of entry. But I, at that time, wanted to belong too eagerly to my class of eager undergraduates, wanting to learn and understand the world through the borrowed lens of an imagined centre. Working through "Ruined Gopuram" as exotic rendered Jaffna itself exotic and unattainable; it denied me an entry point into being Sri Lankan and into Sri Lankan English, through the intimacy of place, of belonging. As Fanon puts it in Black Skin White Masks, I am doubly alienated. (Ironically) in the lecture room at Peradeniya, I was much more at home with Dickens, because he was equally exotic to me as to all of my other Colombo-Kandy based fellow students.

\footnotetext{
${ }^{4}$ It is much later that I learnt about the Jaffna Youth Congress, Prof.

Kanabathipillai and others. I had known of Arumuga Navalar, the Tamil and Hindu revivalist, having lived on the road named after him for years in Nallur. I had known that he was die-hard casteist; but it was much later that I knew that during the Dutch period, in Nallur, which became a point of pilgrimage for Hindus in the $20^{\text {th }}$ century, local 'Tamils' had driven the local Muslim population away by dumping slaughtered pigs into the wells there.
} 
Let me back track a little here, to the formation of the Sri Lankan state, the birth and the birth pangs. Peradeniya is surrounded by thriving and withering tea plantations and is sheltered and shadowed by the high rising mountains of Galaha and Gampola leading us to the tortuous roadway to Nuwara Eliya on one side and the commercial centre of Kandy on the other. The plantation Tamils could not enter the portals of Peradeniya, 'less open than usual ${ }^{5}$.' Under pressure of aesthetic considerations, which have a validity precisely because as an 'empty' signifier, a canon can be established, a canon that partakes in the politics of canonization, through the deployment of some 'arbitrary' categories of aesthetics. ${ }^{6}$ While we spoke of Giraya and the decadence of the aristocracy of the hill country, the labouring 'Tamils' of the plantations continued to labour; they could not become proper subject matter. The single course on Sinhala and Tamil literature that was introduced later to the honours degree syllabus at the Department of English focused on canonical Tamil literature and not on the margins. We never spoke of C. V. Velupillai and his poems or stories. C. V. Velupillai wrote in both English and Tamil. The political bilinguality of his writings, his insight into the 'folk lore' of the estate people, and their becoming non-Sri Lankan-Sri Lankans through colonialism and the disenfranchisement of the Plantation workers in ' 48 and " 49 was sadly missing in the make up of the Sri Lankan English writer. Though I knew of C. V. Velupillai, it was only much later when he was partly 'canonized' in Valentine Daniel's Charred Lullabies that I became more cognizant of his contribution to the making of the literary map of Sri Lanka from an oppositional stance.

One wonders about the kind of enabling that goes on here. One does not wish to speak only about the canon and the curriculum. It is important to put C. V. Velupillai too under the impress of class, gender

\footnotetext{
${ }^{5}$ The motto of the University, initiated by its celebrated architect, the liberal Englishman, Ivor Jennings is, 'More Open than Usual'. Ironically, Peradeniya with its imposing architecture and sprawling grounds, for many years symbolized the notion of the ivory tower model of university education.

${ }^{6}$ To date, nobody has convincingly explained to me what exactly nonpolitical/textual aesthetic considerations are. I, for one, have a kind of belief in a formulation of aesthetics that is deeply political. Politics gives life to beauty in the first and final analysis.
} 
and ethnicity. One does not wish here to canonize Velupillai. It is a political inevitability that he as an English writer would always be a marginal figure, pointing to an impossibility, rhetorically. The fragility and the politics of the making of Sri Lanka is one that is perhaps implicitly recognized in Raja Proctor's Illicit Immigrant. But Illicit Immigrant is a forgotten novel. Ernest Macintyre would pick up some of the threads of Illicit Immigrant later in his play "Rasanayagam's Last Riot," but under different circumstances, when ethnicity had become a theme. Also, it was not the 'Kallathoni,' illegal boat person, an epithet flung at the plantation workers and other people of 'recent Indian origin', but the much more centred and dominant Jaffna Tamil who is the protagonist here. In the post-'77 and pre-' 83 millieu, 'Sri Lanka' was not an unmediated space, even for the Sinhala-Sri Lankan English writer. Growing militancy in the north and growing militancy in the south, not without its chauvinist strains, would affect my sense of belonging deeply. Also, my own Marxist leanings, which I brought over from Jaffna, would make me feel uncomfortable with the inevitable exclusivities of the dominant paradigms within which Sri Lankan English writing operated. Giving voice to my own seeking after the elusiveness of Sri Lankan English, I write ${ }^{7}$ :

my teacher talks to me of a sri lankan english vhere is this thing?

tons of shakespeare, shelley, shaw

press upon me.

how to clean rice in English?

(like myth and mother, 12)

But ' 83 changes all that, the dis/articulations of the minority writer. The certainties of the English writer, if there were any, would burst like a bubble with ' 83 . ' 83 opens a can of worms, if one is to approach it in that way; one could not be totally indifferent to the mayhem, the loss of belief that assaulted the psyche of the middleclass person, as an enabler of ethnic identitiy. ' 83 forces the hand of the

\footnotetext{
${ }^{7}$ The poem first appeared in Navasilu 86 and 87 under the title 'In a foreign tongue.' The version given here is taken from like myth and mother.
} 
English writer, whose middleclass friend, colleague, disappears over night from the neighbourhood. It calls for a response. Kamala Wijeratne writes of watching the house of her (Tamil) friend getting destroyed in the poem "Dear Mabs" (A House Divided, 3). The writer is compelled to write into the narrative his/her own ethnicity, at least one predicated on the identities of Sinhala/Tamil/Burgher. Around the same time, in The Smell of Araliya released after July '83, she writes a flagrantly Sinhala nationalist poem, "The Smell of Dutu Gemunu". At this time ethnic articulation even that of a dominant one emerges slowly, but steadily.

After '83, I could write with confidence at the legitimacy of my own seeking and write autobiographically about the elusiveness of Sri Lankan English. ${ }^{8}$ I need to speak from memory here. At Peradeniya, just before the July riots we witnessed a mini riot on campus against Tamil students and staff. A student in the Department of English at the time, I was half shocked to see how deeply invested the subjectivities of my fellow students and staff were in the debates and battles over ethnicity. July '83 for me happened in May '83 at Peradeniya, not only because it would come to be seen as dress rehearsal for the island wide rioting later, but because for me it took place in an academic environment and forced into the open the fault lines of ideological persuasion and ethnicity.

Within this milieu, we find the entry of Jean Arasanayagam, who makes a foray into writing poetry through positioning herself as a victim; her marriage to a Tamil man gives her that entry point both as a victim of Sinhala and Tamil chauvinisms. She began to write most assuredly in the $70 \mathrm{~s}$. With the entry of the ethnic conflict, ethnicity becomes a fit topic for discussion in multiple ways. Arasanayagam is interesting precisely for these reasons. As she says in one of her poems in the collection Reddened Water Flows Clear 'it is only now that identity has become important' (85). 'Identity' has become a possibility. So, the

\footnotetext{
${ }^{8}$ If I have left out other emergences during this time, other articulations, like that of a Muslim, stressed as a Muslim response to ' 83 , it is my own hegemonic laziness I presume. But I do have my own reasons about why a definitive Muslim identity was not articulated as such in this period, which I am unable to go into here, having limited myself to discuss the construction of the English writer's sensibilities and preoccupations.
} 
marginal Burgher identity she assumes most of the time is enabled by the ethnic conflict, giving her Burgher identity a legitimacy as subject material. I have dealt with this emergence of identity via ethnicity extensively in "Becoming Women: Travelling Gender and Identity Politics in Four Women's Texts".

In other ways too, we see ethnic divides slowly raising their head within the English-speaking literati itself. Ernest Macintyre, the playwright, dramatizes Rasanayagam's last riot. Shyam Selvadurai in Funny Boy feels the pressure of rising militancy among the northern Tamils that comes to define ethnicity, not just that of the Tamil but also of the Sinhala. In Funny Boy the militant, chastely coded as an exmilitant, disturbs the equanimity of the middleclass Tamil home, though his being coded as a repentant militant marks the unease one has with confronting militancy head on. ${ }^{9}$ Selvadurai's Funny Boy is often presented as a coming of age, and coming out story in more senses than one. One of the more successful instances of the expression of the ethnic divide and conflict, most successful in its expression of the upper middleclass urban milieu than any thing else, there is an attempt to depoliticise ethnicity, either within the terms of marriage or of a transgressive sexuality that direct us to a point beyond ethnicity, Tamil and Sinhala ethnicity. A sexuality that lies beyond the ethnic divide etc is articulated, somewhat undermining the portrayal of the middleclass Tamil family's inability to make sense of their own insecurity and of those others living less middleclass lives, the ex-militant and the plantation Tamil. Funny Boy does a lot of what the Sinhala-English writer does with regard to emerging Sinhala consciousness. Here, there is a need to connect and identify with a disempowered Tamil polity that one sees in, say, perhaps Giraya and James Goonewardene's Call of the Kirala, Sarachandra's Curfew and the Full Moon. Funny Boy sees a need to go beyond the confines of Cinammon Gardens, but at the same time, is unable to create a subjectivity for those outside of it. The subjects remain securely tied to the Colombo 7 victims of ethnic chauvinism, homophobia and the riots of '83.

\footnotetext{
${ }^{9}$ My point is not that there is something inherently wrong with the Tamil outsider being an ex-militant; rather, the ex-ness of his militancy has little value on its own, which is my issue with this construction.
} 
Thus, ethnicity permeates English writing and becomes foregrounded in the heady days of the ' $80 \mathrm{~s}$ and ' $90 \mathrm{~s}$. The ethnic conflict puts under stress the idea of Sri Lanka. It puts pressure on the English writer who, always uneasy about ethnic emergence, is now compelled to take a stand. The ethnic conflict forces the question of state and the meaningfulness of the notion of state and nation into the open, challenging the writer to take a stand. The burden on the English writer is double now. Privileged as she or he is, the writer perceives a marginality in her/his position. S/he does not properly belong to mainstream Sri Lankan polity. Yet, economically and socially the English writer has much more capital than the average Sinhala speaking writer. The ethnic conflict further exacerbates this alienation. The English writer then could no longer rest assured that marking herself/himself only in relation to Sinhala is enough. There is another pressure on the writer. The conflict insists upon making the English writer commit to a positionality that is marked by ethnicity ${ }^{10}$.

It is within this general enabling condition of ethnicity and the ethnic conflict that I pose the figure of the suicide bomber as setting the limits of subjectivity for the urban persona of the English writer. An unease with the Sri Lankan state underlies much of the writing today. But that unease is externalized and projected outward onto an other. This is how I make sense of the recurrence of the 'suicide bomber' in many stories that I have read in recent writings in Sri Lanka. The suicide bomber has entered, perhaps only temporarily, the repertoire of the short story writer along with the domestic worker and the frustrated housewife. The suicide bomber in fact has replaced the middleclass victim of Black July.

\section{Exploding Myths: Suicide Bomber Stories and Urbanity}

The problematic of the state and nation is something one cannot wish away easily today, at least where the north and east is concerned for the middleclass Sinhala writer. But how does this problematic

\footnotetext{
${ }^{10}$ I feel compelled to footnote Kamala Wijeratne again. In her poem, 'A Second look at Dutugemunu', (19) in Disinherited there is overt and covert criticism of the use the figure of Dutugemunu has been put to by nationalist forces.
} 
manifest and how is it treated and articulated in the writings? That is the question. Wishing to talk about ethnicity, why do I feel the need to focus exclusively on the suicide bomber? How can the figure of the suicide bomber exhaust and encompass the process of deepening ethnicisation of this country and also at the same time mark the emergence of particular modes of subjectivity? It is my thesis here that in the deepening crisis of war and conflict pervading the Sri Lankan state, the suicide bomber sets the limits of subjectivity for the nation. For the English writer more or less securely placed within the urban spaces of the South, the suicide bomber is one way in which the war is brought home, to the city; it enables one to connect to the war waged in the north and east, pervading the lives of the peoples of the north and east and the homes of Sinhala soldiers, outside the homes of middleclass Colombo.

But before I go further into the suicide bomber stories, I want to delineate a trajectory for the English writer viz-a-viz ethnicity and the ethnic conflict as a whole: The subjectivity of the writer and the emergences and limits set by the ethnicity and the ethnic conflict. The motif of the suicide bomber articulates a duality of perspective. On the one hand, it sets limits on the apprehension of the Tamil and the ethnic conflict. Once the suicide bomber has blown herself and others apart, what more is there to talk about? Of what meaning is ethnicity here, under the circumstances? The suicide bomber is at one level a figure of ultimate radicality; the unviability of the state. On the other, the suicide is also marked as loss, loss brought on the people, who are beyond the pale of politics.

The suicide bomber stories I have taken for discussion here are all different from one another. In the story "The Man Within" (41-71) in the collection Moth and Other Stories by Chandani Lokuge, the protagonist is not really a suicide bomber. Here the bomber, who undertakes to place the bomb in his office in order to be able to provide for his son; it rhetorically questions the rhetoric of patriotism. The situation of the underdog here is pathetic; full of pathos. This story is clearly about the other. The English writer has to belong to the Sri Lankan polity, and more securely to the Sri Lankan polity understood as the Sinhala underclass. Ridden with the guilt characteristic of the 
English speaking middle classes and the elite, the English writer makes an attempt to belong to Sri Lanka by connecting herself to a victimized and at the same time doomed underclass. The bomber is really a lowermiddleclass Sinhala man who is unable to provide for his child and undertakes the mission of carrying out a bomb attack. Lokuge, in her story, questions wanton patriotism, a patriotism that cannot deliver the goods to this poor man's child. But at the same time, the depiction of the victim-status of the bomber makes a plea for a reformed state, a reformed Sri Lankan state, to salvage the lower-middleclass Sinhala man from committing moral suicide and fratricide. The Tamil militant in the story is beyond the pale of narrative sympathy.

I move onto Madhubhashini Ratnayake's collection of stories, Tales of Shades and Shadows. Here I do not wish to look at all the stories but bring a few together that may be useful to understand the intersections of class, gender and ethnicity in the English writing of the urban centres. The stories are heavily invested in a middleclass orientation of feminism. What is interesting and at the same time disquieting about this construction is that it sets up an other for this position that is in many ways a classed and/or ethnic fe/male other. Madhubhasini Ratnayake sets up a critique of patriarchal identifications and ideologies. That is her strength. The housewife stories are in a way the most engaging as a self-reflective narrative voice breaks through the middleclass setting. This is double edged, and does not fall into a simple binary of good and bad. The first story about the cat's taking over the fripperies of a suburban household touches on the demonic side of the woman. There is no stable subject here.

But the writer cannot stay within the housewife mode. The stories in the collection have a repertoire of figures that impinge on Sri Lankan history and society. We have what I call the JVP story, an evocative story called "Circles and Chalk" (65-68) and an LTTE story in the collection. The JVP story is about a teacher in a university trying to teach Brecht to male students who have experienced violence, whose lives have been touched by political violence that leaves the teacher guilt ridden and traumatized. This story within the repertoire connects her/the teacher and writer to a general Sri Lankan/Sinhala subjectivity. The guilt is channeled through a certain identification with and yet 
classed distance from the students who remain by and large the other. But interestingly, by rendering all 'radical' students as the other and male, the writer recycles a rather commonplace operation of middleclass womanhood-the erasure of woman as a classed subject. The guilt felt by the woman underlies the class consciousness evident in the story; at the same time, it serves to assuage or underplay the sharpness of class distinction. I of course have the other story, the story of the suicide bomber in mind here and use it as my entry point into the writer's subjectivity. In the story of the suicide bomber I find the sharpest instance of social assimilation and conservatism at play. The story called "The Vegetable Seller" (26-29) unambiguously sets up an other, who, hailing from the war-torn space of Jaffna, is unattainable. But in our liberal discourses, we need to maintain a non-racist stance that is nevertheless non-threatening. In the story, the writer creates an identity of a middleclass woman who had not cared about the war or the suffering of war victims, secure in her marriage to a caring and successful middleclass man until a suicide bomb takes the life of her husband, shattering her home. Mobs turn upon the ageing Tamil vegetable seller down the street. We have a range of male characters, from the nice caring middleclass Sinhala man to vegetable seller, Muttu, and the young Tamil man from Jaffna, the would-be suicide bomber. The character of Muttu mediates relations between the Sinhala and Tamil polities. He is acceptable. Is he more acceptable than the suicide bomber because as the suffering victim of violence, he depoliticizes the privilege of middleclass securities?

There is a certain romanticisation of Jaffna and the victimization of people in Jaffna that the story undertakes to carry out, undertaken, I feel, in an attempt to counter balance the antipathy one might feel toward the suicide bomber who takes the lives of so many people, including that of the protagonist's husband. But when suffering Jaffna is replaced by the figure of the aggressive suicide bomber, Colombo is threatened. The vegetable seller as a rather humble vendor in Colombo is an honest, hard working Tamil man who is acceptable to the middleclass sensibilities of the young woman. The young man from Jaffna is only a figure who gazes at the peak of Twin Towers and the central bank he would demolish later on. But the suicide bombing 
shatters the sense of marital security of the female narrator, whose life has had meaning in her connection with her husband. What is the pathos of that line, when the threat to the home comes from the outside? It is an ambiguous ending, and finds a resolution in the pathos of loss.

The limits of subjectivity are set clearly on one side by Muttu and the suicide bomber. We have a Sri Lankan subjectivity in the making here that excludes any potential engagement with the subjectivity of the suicide bomber. But more seriously than that, it excludes an engagement with the politics of divide, the politics of ethnicity. The womanist sensibility is accommodative of and subsumes under its fold a mosaic of class and ethnic identifications that are subordinate to the over arching and ethnically neutral marital home. The female other is already under erasure.

The limit of the writer as woman, as middleclass woman is predicated on the silent spectacle of the Tamil man, conjured up as the suicide bomber. Interestingly, the question concerning Muttu and his identity and identification are also left unanswered. The subjectivity of the young woman and the writer insert themselves into the urban spaces as humans and suffering humans, who are nevertheless lost. It is the suffering of Muttu that remains inexplicable and thereby powerful. I quote from the last paragraph here.

I walked through slowly through the rubble and the smoke and my feet took me down the road that I had always gone. Ahead of me I could see the vegetable cart, overturned. The pumpkin had smashed its flesh on the black car. The torn limbs of the long beans hung around the broken pieces of the board. Red tomatoes oozed out from a corner. I sat down. And I thought I should tell you that then, from somewhere, I thought I heard an old man crying. (29)

These are early works of this writer's corpus; while she goes onto write far more challenging works later, I take this first set of stories to talk about the place that a "suicide bomber" occupies in the southern urban setting. Ameena Hussein's suicide bomber story, "An ordinary death" (1-6) in her collection Zillij, deals with the innocence of the down trodden, the honest working class or lower-middleclass petty trader who gave no trouble to anybody. In her story, the petty trader's innocence is 
shattered by the unexplained act of the suicide bomber. What is compelling about this story is the relationship between the upper middleclass woman of ambiguous or inconsequential ethnicity and the Sinhala man who dies. Of all Hussein's stories in this collection, I found "Muslim on the Periphery" (7-22) to be the most powerful and provocative. This story, perhaps the first of its kind in terms of ethnic play, makes a self-conscious and yet disingenuous meta engagement with the constructions of ethnic identities. Yet, Hussein too in the final analysis, and in this story as well, is constrained by the limitations of class that dog the heels of many of the English writers examined here. The suicide bomber story highlights that limitation the most, as neither the bomber nor the suicide seem to sit well with the comforts assumed by the middleclass English writer.

Elmo Jayawardene's Sam's Story is a novel that extends the pathos brought on by the destructive nature of the suicide bomber through a compelling narrative of the goodness of the middleclass master who is beyond ethnicity. The novel concludes with a suicide bombing in which the upperclass benefactor of Sam, the rural boy and the protagonist, whom the benefactor has taken into his homestead, is killed, underlying the pathos of deaths brought on by suicide bombings. The death is not only meaningless, but also undermines the good will that Sinhala people have toward Tamils. The killing of the suicide bomber is depoliticised, upholding an innocence that lies beyond politics. The story epitomizes, given its extended narrative, the middleclass Sinhala-based centrism of suicide bomber stories. In Visakesa Chandrasekaram's play Forbidden Territory, there is a courageous attempt to create identity, a resistant identity, for the female suicide bomber. Her body is marked as woman and as a militant both coming together in a frightening spectacle of destruction being strapped with the suicide bombing apparatus. But while the play moves powerfully on the one hand, on the other, the subjectivity of the woman becomes predictably clichetic and rhetorical. Forbidden Territory bespeaks the limits of romance in the face of the action of the female suicide bomber and the ethnic conflict. The romanticism apparent in all the other suicide bomber stories discussed above, centering the lower-middleclass, or the marginal Sinhala sensibility in some cases, is challenged by 
Forbidden Territory. But there is another kind of containment that takes place in the play; attempts to sexualize her in predictably masculine terms that speaks of the limitations of speaking for the suicide bomber. ${ }^{11}$

In this rendering of ethnicity and location, I have deliberately stayed away from the works on the riots of '83, Monsoons and Potholes by Manuka Wijesinghe and the more recent The Island of a Thousand Mirrors by Nayomi Munaweera, largely because they are well known and have been written about quite widely in recent years, but also because none of them seem to depart from the familiarity of the familial and the Sinhala and Tamil dichotomy. ${ }^{12}$ Despite certain moments of ambivalences, here and there, these works are shaped by their middleclassness and do little to question the foundational myths concerning ethnic marking, classed and gendered. Vivimarie Vanderporten's in her collection of poetry Nothing Prepares You does try to invoke a consciousness of the deep strife shaping ethnicity today. Her works demonstrate a certain sense of accomplishment in crafting emotion, the pathos of the personal. Yet, despite the sensibility, there is little that marks Vanderpoorten as different from any other writers discussed in this section. Nothing Prepares You draws the middleclass contours of the urban English writer too comfortably, and one might say, even complaisantly.

\footnotetext{
${ }^{11}$ The figure of the female suicide bomber is one of fascinating spectacle in Sri Lankan folk lore. When I first performed 'In the Shadow of the Gun,' in Colombo 1998, a feminist activist asked me whether I had not thought of having the suicide bomber in my stories of women performed there. I was quite taken aback, not knowing at that time how to explain away this gross oversight of mine! Later in the play 'Wanted Woman' (2000), I integrated the figure of the suicide bomber as pure spectacle. And again, in my short film, Oranges, I plant the figure of the suicide bomber quite arbitrarily in the middle of the film. The suicide bomber, female suicide bomber, does engage the imagination of the academic too, going by articles written in English about this figure, and her purported subjectivity.

${ }^{12}$ Once again, for the same reason I have left out an analytic reading of The Road to Elephant Pass by Nihal Silva.
} 


\section{When Memory Writes: The Crisis of the State and the Writer as Male}

The shifting location of the English writer and her shifting loyalty to other spaces, other politics, takes me back, in full cycle, to Ceylon, Sri Lanka and the spaces of the nation. But in the '90s and in the new millennium, the boundaries delineating the English writer have changed irrevocably. I speak of Sivanandan's When Memory Dies. When Memory Dies, which I long delayed reading, is a very thoughtful book and in many ways the hero of my paper. It is not because it is without faults in the traditional sense. But its faults are its strengths. Very briefly, the novel looks at the rise of trade unionism through the eyes of a (lower middle class) Jaffna-born Tamil man, Saha, whose son, Rajan, later marries the more radical Sinhala woman, Lali. He adopts Lali's baby as his own, and Vijaya, the son, becomes a symbol of the union between the Sinhala and the Tamil communities. While the family ekes out a living in Anuradhapura, during a time of ethnic trouble, Sinhala mobs kill Lali when the family is on an outing in the idyllic and pastoral surroundings, at the site of one of the sacred historic tanks, for being a traitor to the nation (Sinhala nation) by marrying a Tamil. Inconsolable Rajan leaves the country and settles down in England, not happily. Vijaya grows up with his Sinhala grandparents but as half Tamil. He later becomes imbued with the revolutionary spirit and makes contact with the plantation Tamils. While his marriage to Manel, a Sinhala school teacher is predictably unhappy, the romance between him and Meena, the dark and pretty estate woman holds promise. But romance has no place in the novel really. All of these relationships serve a purpose, the greater goal of telling the story of the ethnic conflict and the ethnic nation through the intertwining strands of personal, filial and political histories of the protagonists.

It is a novel of ethnicity and memories of ethnicity. It is notable that the novel intertwines labour politics with ethnicity, one very few novelists or creative writers indulge in. Ethnicity and labour are kept separate in the usual middleclass-based English writing in Sri Lanka. ${ }^{13}$

\footnotetext{
${ }^{13}$ One of the few exceptions to this is First Rising by Somachandra Wijesuriya which has not unfortunately elicited much critical discussion within academic circles.
} 
Perhaps one of the difficult memories of the novel is the early trade union days, where much of the realism lies. The novel has to necessarily begin with the centre, the urban space of Colombo, trade unionism, located at the centre. The heady trade union days of the ' $30 \mathrm{~s}$ and $40 \mathrm{~s}$ can locate the Tamil as a lower middleclass man only, an outsider to class struggles, but an outsider who becomes an insider. The Muslim too is very firmly outside class struggle. Named as Muslim, one cannot get away from the marginality of that naming. But that hailing interpellates the hailer as well, as Sinhala, and as male. It traces, genealogically of course, the emergence of the ethnic state in not just nationalism, but in the identity of class. Union politics is ethnic politics in When Memory Dies. As Qadri Ismail points out, the insertion of the Muslim woman as a beautiful and desirable woman sets the limits of ethnicity for the novel (Ismail 179-211). Through the elusive and seductive figure of the Muslim woman, the contours of the ethnic nation are firmly drawn. The woman is both the other and the limit of the ethnic state. Sivanandan's unease here has to do with his need to bring in the Muslim, but being able to do so only through the hegemonic lens of Sinhala trade union activity. Despite the fact that historically leading labour leaders of the time hailed from minority communities and despite the participation of minority workers in trade union activity, some of whom became the first victims of the draconian colonial and postcolonial state actions as well, going by the novel, left wing activity, and trade union activities of the time, are centred on/around the Colombo Sinhala working-class. This is somewhat off set by the emergence of the estate as another nodal point later in the novel; by that time the novel has set off in its search for ethnicity and the ethnic divide on a more emphatic note.

The novel is melodramatic both in structure and in theme; it has a certain contrivedness in the way it continually brings Sinhalese and Tamils into conjugal relationships only to violently tear them asunder. But unlike the usual mawky platitudinous resolutions of intermarriage', popularized in the colloquial as holding the promise of the future by mainstream Sinhala writers, or as in the case of Sam's Story, offering the hand of friendship to Tamils, intermarriage is not a panacea for Sivanandan. The deployment of the 'device' of inter-ethnic marriage is largely allegorical. The two sets of intermarriage and love affairs of 
two different generations, the first between Rajan and Lali and the second between Vijaya and Meena, are metaphors of the nation, the Sri Lankan nation, limping along and finally breaking up. It is a national tour de force, wending its way from the heady trade union and left wing activism of the 1950s to the slow disintegration of Tamils in mainstream and left wing politics, the exploitation of plantation workers, the JVP uprising of 1971 and the ultimate show down brought on by Tamil militancy turned inward. The protagonist of the second half of the story, Vijaya, is embraced as Tamil by the extended family of his stepfather. $\mathrm{He}$ is later killed by his militant (LTTE) Tamil cousin, Ravi, which encapsulates for me the tragic consequences of the crisis of the nation here. Here the Tamil militant is not outside the pale of a dominant Sri Lankan state. He and she are part of the collapse of both dominant Sinhala and Tamil nations, constructed through a variety of patriarchal significations. The death of the central character Lali, the Sinhala mother of Vijaya, at the hands of anti-Tamil rioters signifies to an even greater measure the failure of the patriarchal state to hold its people together. The three main female figures, Lali, Manel and Meena, stand in for various notions of the nation and its subjects. All three of them point to the way the nation is built, coheres or collapses. Lali, for instance, is not just a mother. She is the one who tries to bring the Sinhala and Tamil sides of her family together, picked up by Vijaya later.

Unlike Qadri Ismail and many others I have spoken to, who see the second half of the book as much weaker than the first, I see in the melodrama and in the metaphoric of the second half, as opposed to the realism of the first, the crisis of the nation and the crisis of the masculine nation. Nothing is left untouched by politics here. The killing of Vijaya by his cousin is fratricide like that of the Tamils by Sinhala rioters earlier. The strength of the novel lies in its theoretical take on masculinity. It is the crisis of masculinity as well as the crisis of nation that the novel deals with. This crisis then has to do with ethnicity and the ethnic conflict as well. By the end of the story, is no longer outside of the story; with the death of Vijaya and Rajan, the writer marks the crisis within the subjectivity of the Sri Lankan writer as well. As Ismail has painstakingly shown, the limits of Sivanandan's very conceptualization 
of the working class struggle, the Sri Lankan state and ethnicity, is set by the inability of the national imagination to place the Muslim within a national/nationalist consciousness. This happens to a lesser extent with the Tamils of the Plantation. The narrative in its second half makes a full-blown overture to the plantations; in the national or more specifically anti-nationalist imagination of the narrative.

Writing of Ceylon as much as of Sri Lanka, in the late '90s, of the nation-state in the making in the early years of independence, Sivanandan writes of the collapse of the nation, not a celebration of it. He writes of the collapse of the masculinity of the nation. This is where I diverge much from Ismail's critical account of When Memory Dies, as being male and as projecting a male dominant narrative. If When Memory Dies revolves around men, it does so as a collapse of leftwing masculine activity as political action. When Memory Dies is about the death of the male writer as protagonist, the death of the male protagonist as the harbinger of peace, stability and more importantly in the thrust of the novel, in the forging of the multi-ethnic and revolutionary nation. The death of the male hero is clearly written in the pages of the book, male as it may be. Vijaya as the protagonist-son bringing the Tamil and the Sinhalese together enacts another impossibility, a solution to the crisis of nation, enacted by its male heirs.

But masculinity is already in crisis as I see it. The masculine contours of the nation are in crisis: borders as rigid and requiring military might, soldiers who are patriarchally assumed, following in one's father's foot-steps, protecting the mother land. Vijaya also follows upon his mother's legacy as much as his father's. It is in the loss of Lali in the first half and in the emergence of Vijaya and Meena, the woman from the plantation, that the novel travels from the urban middleclass moorings to a seeking of a solution. Ismail sees the second part of the novel as structurally weak, lacking in the 'real,' like the Tamil militant in Funny Boy. But unlike the good and wholesome ex-militant who has properly given up his terrorism for whatever reason, Vijaya is not a figure of middleclass reality. The strength of the novel then rests on that unreal. 
Lali, whom I see as the most central woman figure in the novel, is an enabler. She enables a drawing of the nation that is different from the divisiveness of masculine mobilizations making the nation. On the other hand, the woman from the plantation, who evokes great sympathy in Vijaya is the vanishing point of land and class that the novel so difficultly grapples with. Both Lali and Meena come to stand for woman as class and ethnicity, not the divisive ethnicity of the rioters or of the politicians, or the individuated inabilities of Rajan and Vijaya. Lali the woman maintains links with the Jaffna-based Tamil family of Rajan. She dies, in the name of ethnicity, at the hands of rioters. Within Sri Lanka, the woman becomes a figure of both agency and impossibility.

When Memory Dies, in its travels, from Colombo to Anuradhapura, Hatton, and finally Jaffna, points to a dispersal and a shifting of locations, which carry serious implications for any study of English writing. Is it possible to shift centres at all where English is concerned? Could Sivanandan have enabled that from his 'comfortable' home in London? While in Funny Boy transnationality enables the diaspora to write of Sri Lanka, as sexually and ethnically situated, it cleanses the space abroad of some of these aspects. But this is not the case with When Memory Dies. The transnational does not offer a place of solace or emergence. When Rajan moves to Britain, to live out the remainder of his sad days there, the diasporic space becomes autobiographically performative, not realistic. It is the sadness one hears of, his insanity, a position of impossibility, of no return. But materially speaking, how does one enable that possibility, the search I had embarked upon in my poem, for the Sri Lankan English speaker, when I first set out from my home in Jaffna?

When Memory Dies also speaks of a crisis for the writer who is centred in Colombo. The English writer in Sri Lanka today is perhaps a much more divided, disillusioned, and dispersed person than that of twenty-five years ago. Ethnic emergence is fraught from the beginning of times. The crisis of ethnicity itself is marked, but it is the crisis of the state that makes it the tragic novel it is. If we take the woman as the contestant in the final analysis of the novel, then the novel begins to engender interesting possibilities. For my purposes here, I stress the significance of the novel's place within the body of English writing in Sri 
Lanka. When Memory Dies writes the question: Who is the English writer, is he there? Who do we remember and commemorate as the English writer in Sri Lanka or even as English writing?

In routing itself toward viable alternatives, the novel points to other centres, and at the same time, to the inability of those other centres, Jaffna and Tamil nationalism. These other centres are torn apart by nationalist claims, caste, and gender hierarchies and assertions. However, this pointing to is important for me to explore in greater depth those locations, which are geographically, linguistically, socially and politically, the other. Sonali Perera, in fact, identifies a lack of centre in the novel, in her compelling theorizing of the novel as a visionary statement on black working-class postcolonial struggles in history (81), and her view is in line with my own thinking. Is writing from the margins important? The conflict has produced conflicts. But with international schools supplanting private schools, increasing social cleavages, at one level, increase the possibility of a certain kind of complaisance for the English writer, in what is called today's world of globalisation. There may be trajectories for the English writer that I have not been able to anticipate at all. There is a certain dispersal of the English writer that is not only regional, but also continental and global.

But I stop here, for those identifications and pursuits belong to another time, another space and other pleasures of reading, writing and belonging. My journey through time reading Sri Lankan English has come a long way, and the Sri Lankan writer in English too seems to be of many persuasions. I write another poem, in groundviews.com, "sri lankan english poem ii," reproduced in full here, pointing to the multiple absences that we carry in our tongue, alien and otherwise.

my teacher talks of a sri lankan english-poem ii

(a responsive thing)

ooo, how sad that

thing called a sri lankan-thing

who

thinging this thing of

of englees or inglisss

has no capacity, no?

for funny funny joking thing 


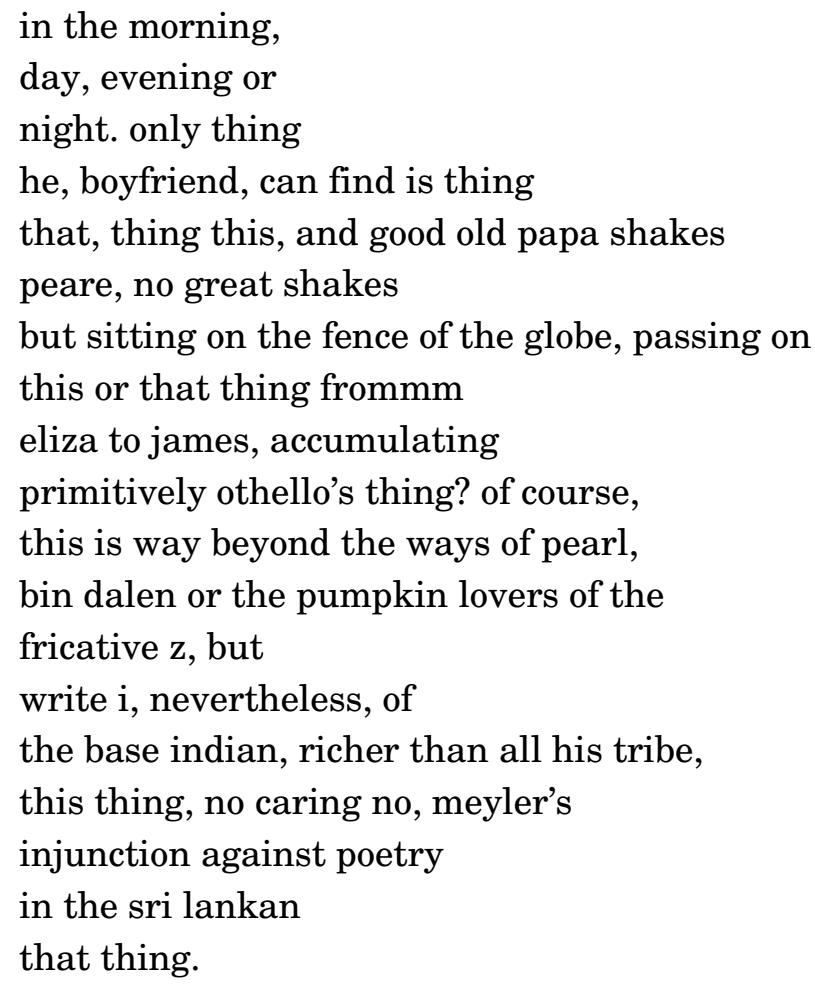

\section{Works Cited}

Arasanayagam, Jean. 'Ruined Gopuram', Kindura: poems by Jean Arasanayagam. Kandy. 25. 1973.

---. Reddened Water Flows Clear. London: Forest Books, 1991.

Chandrasekaram, Visakesa. Forbidden Territory. Colombo, ICES, 2000.

Daniel, Valentine. Charred Lullabies: Chapters in an Anthropography of

Violence. Princeton, N. J: Princeton University Press, 1996.

D. C. R. A. Goonetilleke. Sri Lankan English Literature and the Sri Lankan People 1917-2003. Colombo: Vijitha Yapa, 2005. 118-121.

Hussein, Ameena. Zillij: stories. Colombo: Perera-Hussein Publishing

House, 2003.

Ismail, Qadri. Abiding by Sri Lanka: on peace, place and postcoloniality.

Minnesota and London: University of Minnesota Press, 2005.

Jayawardene, Elmo. Sam's Story. Colombo: Vijitha Yapa Publications, 2001.

Lokuge, Chandani. Moth and other stories. Sydney, Australia: Dangaroo Press, 1992. 
Macintyre, Ernest. Rasanayagam's last riot. Sydney, Australia: Worldlink, 1993.

Munaweera, Nayomi. The island of a thousand mirrors. Colombo: $\mathrm{PH}$ publishers, 2013.

Perera, Sonali. No Country: working class writings in the age of globalization. New York: Columbia University Press, 2014.

Proctor, Raja. Illicit Immigrant. Lake House, 1977.

Ratnayake, Madhubhashini. Tales of shades and shadows. Colombo: Vijitha Yapa Publications, 2002.

Santhan, Aiyathurai. The Whirlwind. Chennai: V.U.S. Pathippagam, 2010.

Selvadurai, Shyam. Funny Boy. New Delhi: Penguin, 1994.

Silva, Nihal de. The road from Elephant Pass. Colombo: Vijitha Yapa, 2003.

Sivanandan, Ambalavanar. When Memory Dies. London: Arcadia, 1997.

Sumathy, Sivamohan. "Becoming Women: travelling gender and identity politics in four women's texts." Indian Women's writing. Ed. R.K Dawan \& A. Monti, 2002. 247-293

---. Thin Veils: In the Shadow of the Gun \& Wicked Witch performing act/ivism. Colombo: ICES, 2003.

---. "The Middle Passage: migration and displacement of Sri Lankan Tamil women of the diaspora." Socio-Legal Review (2005): Vol. 1. 1. 11-29.

---. like myth and mother, a political autobiography in poetry and prose. Colombo: sirahununi, 2008.

---. "my teacher talks of a sri lankan english - poem ii". 5 July, 2010. www. groundviews.com.

Vanderpoorten, Vivimarie. Nothing Prepares you. Colombo: Zeus Books, 2007.

Wickremesekera, Channa. Distant Warriors. Colombo: Perera-Hussein Publishing House, 2005.

---. In the same boat. Colombo: Bay Owl Press, 2010.

Wijenaike, Puniyakante. Giraya. First Edition. 1971. Padukka, Sri Lanka:

State Printing Corporation, 1992.

Wijeratne, Kamala. Nov. 1983. The Smell of Araliya. Kandy.

---. A House Divided. Ambatenna, 1985.

---. Disinherited. Manuscript. 1986.

Wijesinghe, Manuka. Monsoons and potholes. Colombo: PH publishers, 2005.

Wijesuriya, Somachandre. First Rising. Battaramulla, Sri Lanka: Rupana, 2001. 